\title{
Pharmacokinetics of Gefitinib in a Patient with Non-Small Cell Lung Cancer Undergoing Continuous Ambulatory Peritoneal Dialysis
}

\author{
Teppei Yamaguchi Sumito Isogai Takuya Okamura Sakurako Uozu \\ Yuki Mieno Tami Hoshino Yasuhiro Goto Masamichi Hayashi \\ Toru Nakanishi Kazuyoshi Imaizumi \\ Division of Respiratory Medicine and Clinical Allergy, Department of Internal Medicine, \\ Fujita Health University, Toyoake, Japan
}

\section{Key Words}

Gefitinib - Continuous ambulatory peritoneal dialysis - Chronic renal failure - Epidermal growth factor receptor · Non-small cell lung cancer

\begin{abstract}
A 72-year-old man undergoing continuous ambulatory peritoneal dialysis (CAPD) for chronic renal failure and who had undergone right upper lobectomy for lung adenocarcinoma (pT2aNOM0) 2 years ago was admitted for recurrence of lung cancer presenting as multiple brain metastases. An epidermal growth factor receptor mutation analysis of his lung cancer revealed a deletion of 15 nucleotides (E746-A750) in exon 19. After whole-brain radiotherapy, we started daily administration of $250 \mathrm{mg}$ gefitinib under the continuation of CAPD and performed a pharmacokinetic analysis. We speculated that the plasma concentration of gefitinib reached the steady state at least by day 16 after the start of gefitinib $(626.6 \mathrm{ng} / \mathrm{ml}$ at trough level). On day 46, the plasma concentration was $538.4 \mathrm{ng} / \mathrm{ml}$ at trough level and the concentration in the peritoneal dialysis fluid was $34.6 \mathrm{ng} / \mathrm{ml}$, suggesting that CAPD appeared to have little effect on the pharmacokinetics of gefitinib. During gefitinib therapy, there were no significant adverse events except for grade 2 diarrhea. Gefitinib could be safely administered to a patient undergoing CAPD.

c) 2015 S. Karger AG, Basel
\end{abstract}

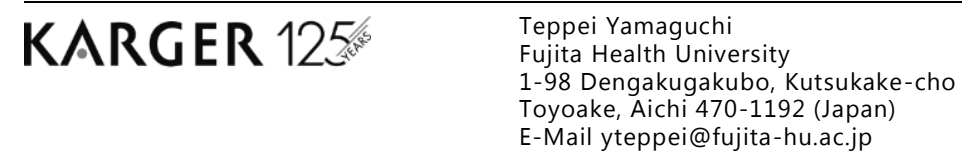


Yamaguchi et al.: Pharmacokinetics of Gefitinib in a Patient with Non-Small Cell Lung Cancer Undergoing Continuous Ambulatory Peritoneal Dialysis

\section{Introduction}

The administration of gefitinib, a selective tyrosine kinase inhibitor of the epidermal growth factor receptor (EGFR), is one of the standard therapies for patients with advanced non-small cell lung cancer (NSCLC) harboring EGFR mutations $[1,2]$. As its toxicity is less than that of cytotoxic anticancer agents, gefitinib can be administered to patients ineligible for cytotoxic chemotherapy because of poor organ functions. Previous studies have demonstrated that EGFR mutation-positive patients with a poor performance status or advanced age can benefit from gefitinib as the first-line treatment [3, 4].

Chronic kidney disease defined as the presence of reduced kidney function, or kidney damage, has become a worldwide health problem. The gradual loss of kidney function is irreversible and can progress to end-stage kidney failure, which is fatal without artificial filtering (dialysis) or a kidney transplant. Continuous ambulatory peritoneal dialysis (CAPD), a treatment modality which uses the patient's peritoneum as a dialysis membrane, has been widely used for patients with irreversible renal failure.

Gefitinib is mainly metabolized by the liver, and its renal elimination is $<4 \%$ [5]. There have been several reports on the pharmacokinetic (PK) analysis of molecular targeted drugs administered to patients with end-stage renal disease [6, 7], and a recent paper reported that gefitinib could be safely administered to a patient with NSCLC undergoing hemodialysis for chronic renal failure [8]. Successful rituximab and bendamustine treatment has been reported in the case of a chronic lymphocytic leukemia patient undergoing CAPD [9]. To the best of our knowledge, no reports have been published describing the pharmacokinetics of molecular target drugs including gefitinib in patients on CAPD. This is the first case report with a PK analysis of gefitinib in a patient with NSCLC undergoing CAPD.

\section{Case Report}

A 72-year-old man, never-smoker, who had been undergoing CAPD for 2 years for chronic renal failure due to diabetic nephropathy, was diagnosed with lung adenocarcinoma. Subsequently, he underwent right upper lobectomy (pT2aN0M0). Two years later, he complained of disturbed consciousness, and his brain CT scan revealed multiple brain metastases. Whole-brain radiotherapy with 30 Gy in 10 fractions was immediately started. An EGFR mutation analysis of his lung cancer (fragment analysis; SRL Inc., Tokyo, Japan) revealed a deletion of 15 nucleotides (2236-2250) in E746-A750 of exon 19. He was continuing CAPD with the prescription of an exchange of 2 liters 3 times per day. We started gefitinib (250 $\mathrm{mg}$ ) administration once a day and performed a PK analysis. After obtaining written informed consent, blood samples were collected before and $12 \mathrm{~h}$ after the administration of gefitinib on days $1,3,8,16,46$, and 47 . The gefitinib concentration in the plasma was measured by high-performance liquid chromatography with tandem mass spectrometry detection at Shin-Nihon Kagaku Co., Ltd., Wakayama, Japan. On the first day of gefitinib treatment, the plasma concentration $12 \mathrm{~h}$ after administration was $230.8 \mathrm{ng} / \mathrm{ml}$. On the third day, it was $340.2 \mathrm{ng} / \mathrm{ml}$ before dosing (at the trough level) and $416.5 \mathrm{ng} / \mathrm{ml} 12 \mathrm{~h}$ after taking gefitinib. The gefitinib concentration increased to 626.6 and $670.0 \mathrm{ng} / \mathrm{ml}$ (before and $12 \mathrm{~h}$ after dosing, respectively) on day 16 . On day 46 , the concentration was $538.4 \mathrm{ng} / \mathrm{ml}$ at the trough level and $609.2 \mathrm{ng} / \mathrm{ml} 12 \mathrm{~h}$ after taking gefitinib. Thus, we concluded that the plasma concentration of gefitinib had reached the steady state by day 16 at the latest (fig. 1). We also measured the gefitinib concentration of third-space fluid, namely, pleural effusion and peritoneal effusion (drained dialysis solution after $6 \mathrm{~h}$ of incubation) on day 46. The gefitinib 
Yamaguchi et al.: Pharmacokinetics of Gefitinib in a Patient with Non-Small Cell Lung Cancer Undergoing Continuous Ambulatory Peritoneal Dialysis

concentration of in the pleural and peritoneal effusion was 274.2 and $34.6 \mathrm{ng} / \mathrm{ml}$, respectively. The pleural effusion was transudative, and the gefitinib concentration in the pleural fluid was about one third of the plasma concentration. The concentration ratio of gefitinib in the dialysis solution was about $5 \%$ of the concentration in plasma. During gefitinib therapy, the patient received some blood transfusions for grade 3 anemia; however, he had had renal anemia before starting gefitinib treatment. He also developed grade 2 diarrhea but did not have other adverse events including rash, fatigue, or appetite loss. After whole-brain radiotherapy and gefitinib administration, the brain metastases had improved, and there was no apparent disease progression observed on chest CT (day 46) and brain MRI (day 41).

\section{Discussion}

We report the first PK analysis of gefitinib in a patient with NSCLC undergoing CAPD. The analysis revealed that the gefitinib concentration reached the plateau level on day 16 after the start of gefitinib administration at the latest. In addition, its concentration in the peritoneal dialysis solution after $6 \mathrm{~h}$ of incubation was about $5 \%$ of the plasma concentration. This indicates that the patient's CAPD appeared to have only a small impact on gefitinib clearance and the pharmacokinetics of the drug. However, it is noteworthy that there are considerable differences in the contents of dialysis solutions or the times and volume of dialysis fluid exchange among individual CAPD patients [10]. If a peritoneal inflammation such as peritoneal metastasis or infection were present, drug penetration into the peritoneal cavity would increase. Thus, the gefitinib clearance by CAPD may vary depending on the dialysis condition.

The plasma concentration of gefitinib at the plateau level in our patient was considerably higher than that in a previous report with $225-\mathrm{mg} /$ day administration to patients with solid tumor (table 1) [5]. Our patient had pleural effusion in which we detected gefitinib at about one third of the plasma concentration. Gefitinib distributed into third-space fluid could be slowly released, resulting in the prolongation of its terminal half-life in the plasma. Thus, we speculated that the gefitinib concentration in the pleural effusion might have induced a high plasma concentration of gefitinib in the present case. Masago et al. [11] described plasma and pleural fluid pharmacokinetics of erlotinib, a mean penetration rate from plasma to pleural fluid of $18 \pm 11 \%$ on day 1 and $112 \pm 72 \%$ on day 8 , and plasma PK data on day 1 and day 8 which were slightly higher than those previously reported. Despite the elevated gefitinib concentration, the toxicity in the present case was relatively mild. This may be partly because the usual clinical dose of gefitinib ( $250 \mathrm{mg} /$ day) is only one third of its maximum tolerated dose $[12,13]$.

In summary, a PK study of gefitinib in a patient receiving CAPD indicated that peritoneal dialysis had little effect on the elimination of the drug and the plasma concentration could reach the stable level at around 2 weeks. However, as the pharmacokinetics and safety of gefitinib in patients on CAPD might depend on the individual condition, further studies are warranted.

\section{References}

1 Maemondo M, Inoue A, Kobayashi K, Sugawara S, Oizumi S, Isobe H, Gemma A, Harada M, Yoshizawa H, Kinoshita I, Fujita Y, Okinaga S, Hirano H, Yoshimori K, Harada T, Ogura T, Ando M, Miyazawa H, Tanaka T, Saijo Y, Hagiwara K, Morita S, Nukiwa T; North-East Japan Study Group: Gefitinib or chemotherapy for nonsmall-cell lung cancer with mutated EGFR. N Engl J Med 2010;362:2380-2388. 


\section{Case Reports in Oncology}

\begin{tabular}{l|l}
\hline Case Rep Oncol 2015;8:78-82 \\
\hline DOI: $10.1159 / 000375485$ & $\begin{array}{l}\text { C } 2015 \text { S. Karger AG, Basel } \\
\text { www.karger.com/cro }\end{array}$ \\
\hline
\end{tabular}

Yamaguchi et al.: Pharmacokinetics of Gefitinib in a Patient with Non-Small Cell Lung Cancer Undergoing Continuous Ambulatory Peritoneal Dialysis

2 Mitsudomi T, Morita S, Yatabe Y, Negoro S, Okamoto I, Tsurutani J, Seto T, Satouchi M, Tada H, Hirashima T, Asami K, Katakami N, Takada M, Yoshioka H, Shibata K, Kudoh S, Shimizu E, Saito H, Toyooka S, Nakagawa K, Fukuoka M; West Japan Oncology Group: Gefitinib versus cisplatin plus docetaxel in patients with nonsmall-cell lung cancer harbouring mutations of the epidermal growth factor receptor (WJTOG3405): an open label, randomised phase 3 trial. Lancet Oncol 2010;11:121-128.

-3 Inoue A, Kobayashi K, Usui K, Maemondo M, Okinaga S, Mikami I, Ando M, Yamazaki K, Saijo Y, Gemma A, Miyazawa H, Tanaka T, Ikebuchi K, Nukiwa T, Morita S, Hagiwara K; North East Japan Gefitinib Study Group: First-line gefitinib for patients with advanced non-small-cell lung cancer harboring epidermal growth factor receptor mutations without indication for chemotherapy. J Clin Oncol 2009;27:1394-1400.

-4 Maemondo M, Minegishi Y, Inoue A, Kobayashi K, Harada M, Okinaga S, Morikawa N, Oizumi S, Tanaka T, Isobe H, Kudoh S, Hagiwara K, Nukiwa T, Gemma A: First-line gefitinib in patients aged 75 or older with advanced non-small cell lung cancer harboring epidermal growth factor receptor mutations: NEJ 003 study. J Thorac Oncol 2012;7:1417-1422.

5 Gefitinib (IRESSA 250) prescribing information. Astra Zeneca Japan, 2006.

-6 Togashi Y, Masago K, Fukudo M, Terada T, Ikemi Y, Kim YH, Fujita S, Irisa K, Sakamori Y, Mio T, Inui K, Mishima M: Pharmacokinetics of erlotinib and its active metabolite OSI-420 in patients with non-small cell lung cancer and chronic renal failure who are undergoing hemodialysis. J Thorac Oncol 2010;5:601-605.

$\longrightarrow 7$ Thiery-Vuillemin A, Curtit E, Maurina T, Montange D, Succi C, Nguyen T, Kim S, Montcuquet P, Pivot X, Royer B: Hemodialysis does not affect everolimus pharmacokinetics: two cases of patients with metastatic renal cell cancer. Ann Oncol 2012;23:2992-2993.

-8 Shinagawa N, Yamazaki K, Asahina H, Agata J, Itoh T, Nishimura M: Gefitinib administration in a patient with lung cancer undergoing hemodialysis. Lung Cancer 2007;58:422-424.

-9 Shoji J, Lew SQ: The use of rituximab and bendamustine in treating chronic lymphocytic leukemia (CLL) in end-stage renal disease (ESRD). BMJ Case Rep 2013, DOI: 10.1136/bcr-2013-009637.

-10 Haraldsson B: Assessing the peritoneal dialysis capacities of individual patients. Kidney Int 1995;47:11871198.

11 Masago K, Togashi Y, Fukudo M, Terada T, Irisa K, Sakamori Y, Kim YH, Mio T, Inui K, Mishima M: Plasma and pleural fluid pharmacokinetics of erlotinib and its active metabolite OSI-420 in patients with non-smallcell lung cancer with pleural effusion. Clin Lung Cancer 2011;12:307-312.

-12 Nakagawa K, Tamura T, Negoro S, Kudoh S, Yamamoto N, Yamamoto N, Takeda K, Swaisland H, Nakatani I, Hirose M, Dong RP, Fukuoka M: Phase I pharmacokinetic trial of the selective oral epidermal growth factor receptor tyrosine kinase inhibitor gefitinib ('Iressa', ZD1839) in Japanese patients with solid malignant tumors. Ann Oncol 2003;14:922-930.

13 Ranson M, Hammond LA, Ferry D, Kris M, Tullo A, Murray PI, Miller V, Averbuch S, Ochs J, Morris C, Feyereislova A, Swaisland H, Rowinsky EK: ZD1839, a selective oral epidermal growth factor receptortyrosine kinase inhibitor, is well tolerated and active in patients with solid, malignant tumors: results of a phase I trial. J Clin Oncol 2002;20:2240-2250.

Table 1. Plasma concentration of gefitinib in the present case and reference data from a previous study of Japanese patients with normal renal function [5]

\begin{tabular}{lcl}
\hline & $\begin{array}{l}\text { Present } \\
\text { case }\end{array}$ & $\begin{array}{l}\text { Previous } \\
\text { study }\end{array}$ \\
\hline $\begin{array}{l}\text { Gefitinib dose, mg/day } \\
\text { Concentration at trough level, ng/ml } \\
\text { Day 3 }\end{array}$ & 250 \\
$\quad 340.2$ & $102 \pm 29.1$ \\
Day 16 & 626.6 & $201 \pm 93.91$ \\
\hline
\end{tabular}

1 On day 14. 
Yamaguchi et al.: Pharmacokinetics of Gefitinib in a Patient with Non-Small Cell Lung Cancer Undergoing Continuous Ambulatory Peritoneal Dialysis

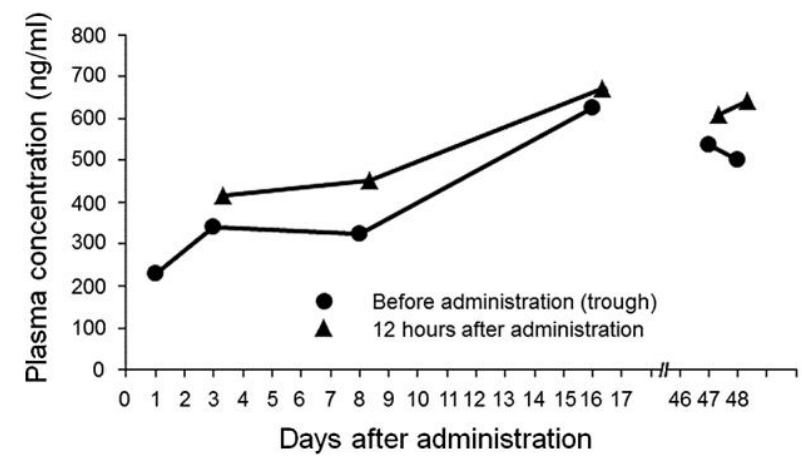

Fig. 1. Time course of the plasma concentration during gefitinib (250 mg/day) administration in the present case. The gefitinib concentration increased to 626.6 and $670.0 \mathrm{ng} / \mathrm{ml}$ (before and $12 \mathrm{~h}$ after dosing, respectively) on day 16 . On day 46, the concentration was $538.4 \mathrm{ng} / \mathrm{ml}$ at the trough level and 609.2 $\mathrm{ng} / \mathrm{ml} 12 \mathrm{~h}$ after the administration of gefitinib. The plasma concentration of gefitinib had reached the steady state by day 16 at the latest. 